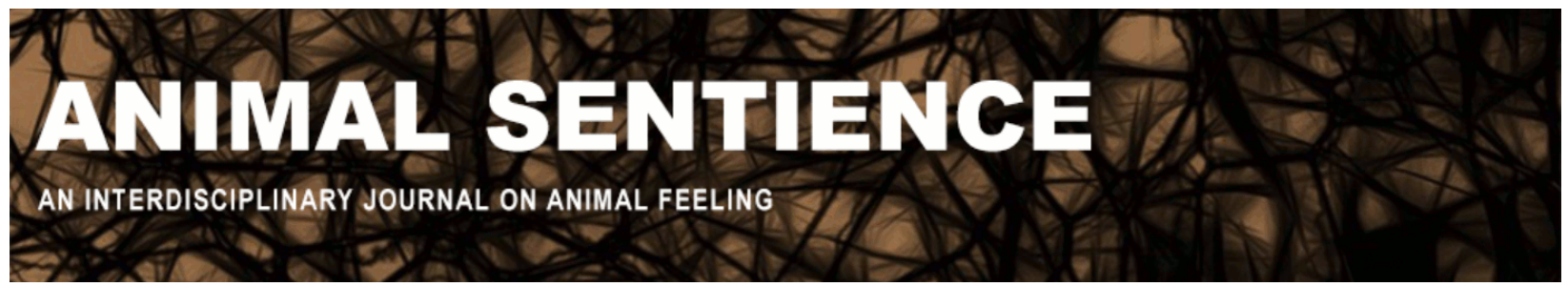

Lester, David (2017) Non-human animal suicide could be tested. Animal Sentience 20(3)

DOI: $10.51291 / 2377-7478.1286$

Date of submission: 2017-12-28

Date of acceptance: 2017-12-31

(c)

This article has appeared in the journal Animal

Sentience, a peer-reviewed journal on animal

cognition and feeling. It has been made open access,

free for all, by WellBeing International and deposited

in the WBI Studies Repository. For more information,

please contact

wbisr-info@wellbeingintl.org.

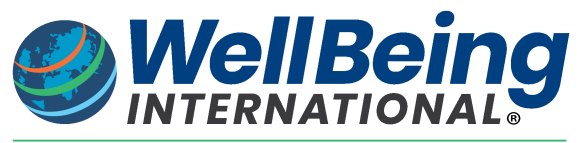

SOLUTIONS FOR PEOPLE, ANIMALS AND ENVIRONMENT 


\title{
Non-human animal suicide could be tested
}

Commentary on Peña-Guzmán on Animal Suicide

\author{
David Lester \\ Stockton University
}

\begin{abstract}
Schaefer (1967) showed that mice can discriminate live from dead mice and lethal from nonlethal environments, and that they avoid a lethal environment; but the experiment lacked some controls. This might be a way to test whether mice would ever choose a lethal environment. Humans may also choose a potentially lethal environment unconsciously.
\end{abstract}

[editorial note: This journal does not publish primary research that harms animals and should not be construed as encouraging it.]

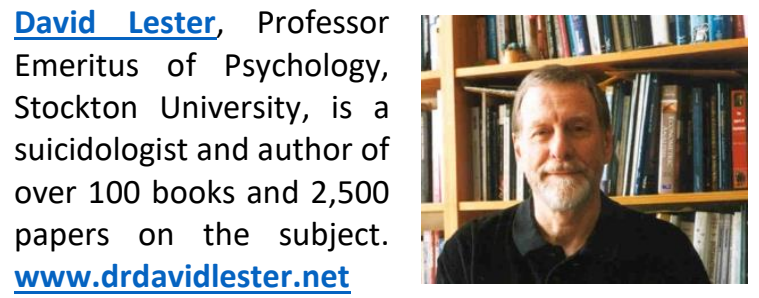

Peña-Guzmán (2017) has provided a powerful argument for the possibility that animals can choose to die by suicide. However, is it possible to prove that an animal can commit suicide?

There has been one approach to this problem that has potential for theory and research. Schaefer (1967), in an essay entitled "Can a Mouse Commit Suicide?", first identified the basic issues involved in deciding whether an animal can commit suicide. (1) Can the animal discriminate between life and death or, to be more specific, between a live animal and a dead animal? (2) Can an animal discriminate between a lethal and a nonlethal environment? (3) Under what circumstances will an animal choose to enter a lethal environment?

Schaefer demonstrated how these questions might be answered. To demonstrate that an animal can discriminate a dead animal from a live one, Schaefer used an operant conditioning technique in which one lever in a Skinner box produced food when a live mouse was the stimulus and a second level produced food when a dead mouse was the stimulus. Schaefer's mice learned this discrimination.

To demonstrate that mice can discriminate between a lethal chamber and a nonlethal chamber, Schaefer allowed mice to choose to enter one of two chambers. In one chamber, they were electrocuted, while in the other, they were allowed to live. The behavior of these mice was observed by other mice. As long as the observed mouse was alive, one lever produced food. When the observed mouse was dead, a second lever produced food. The observing mice learned this discrimination. After learning the discrimination, the observing mice were allowed to enter the chambers. On test trials, the mice entered only the nonlethal chamber. They avoided the lethal chamber. 
If these demonstrations can be replicated (no-one seems to have pursued Schaefer's ideas), it would be possible to investigate under what circumstances an animal might choose to enter the lethal chamber.

In his demonstrations, of course, Schaefer failed to include controls for several factors. For example, are the mice learning to discriminate between a dead and a live stimulus mouse or merely a non-moving and a moving mouse? Would the observer mouse respond differently if, instead of observing mice killed, he observed mice waking from sleep? Perhaps it is the change in the state of the mice that led the observer mouse to avoid the lethal chamber rather than mice being killed? However, these problems could be overcome, and Schaefer's formulation of the problem enables us to plan a set of empirical studies to explore whether an animal could commit suicide.

A second point to make concerns the role of the unconscious. Many explanations of suicidal and self-destructive behaviour in humans involve the role of the unconscious. Menninger (1938), a psychoanalyst who accepted the presence of a death instinct in the human psyche, felt that unconscious self-destructive and suicidal desires could motivate humans. For example, in some cases of victim-precipitated homicide, an individual may provoke a fight, say in a bar, and end up being killed by the opponent. In these cases, it may be possible to conceptualize the behaviour as suicidal even though the deceased had no conscious suicidal impulses. ${ }^{1}$ If suicidal and self-destructive behavior can occur in humans without the presence of conscious thoughts or desires, then conscious thoughts and desires are not necessary in animals.

\section{References}

Menninger, K. (1938). Man against himself. New York: Harcourt, Brace \& World.

Peña-Guzmán, D. M. (2017). Can nonhuman animals commit suicide? Animal Sentience 20(1)

Schaefer, H. H. (1967). Can a mouse commit suicide? In E. S. Shneidman (Ed.), Essays in selfdestruction, pp. 494-509. New York: Science House.

\footnotetext{
${ }^{1}$ If such individuals have been in psychoanalytic psychotherapy, it may be possible to document these unconscious desires using the patients' communications to the analyst, for example, in their dreams and free associations.
} 